\title{
Pengaruh Kebiasaan Merokok terhadap Pembentukan Stain pada Gigi
}

\author{
Serena D. V. Dondokambey, Damajanty H. C. Pangemanan, Johanna A. Khoman
}

\author{
Program Studi Pendidikan Dokter Gigi Fakultas Kedokteran Universitas Sam Ratulangi \\ Manado, Indonesia \\ Email: dondokambeyserena@gmail.com
}

\begin{abstract}
Smoking is a bad habit that has become a necessity of life for some people. Moreover, smoking is found almost everywhere regardless of age, gender, and occupation. One of the consequences of smoking is the formation of stain on the teeth. This study was aimed to obtain the effect of smoking on the formation of stain on teeth. This was a literature review using various databases, such as Google Scholar, PubMed, and Wiley. The most frequent smoking frequency found was light smokers with the number of cigarettes smoked 1-4 cigarettes per day. All literatures showed that more stain formation occurred than no stain formation. Based on the frequency of smoking, the formation of stain on the teeth was most common in smokers with light category. In conclusion, smoking habits can affect the formation of stain on teeth. Based on the frequency of smoking the formation of stain on teeth is most commonly found in lightcategory smokers.
\end{abstract}

Keywords: smoke; stain; discoloration

\begin{abstract}
Abstrak: Merokok merupakan salah satu kebiasaan buruk yang sudah menjadi kebutuhan hidup oleh sebagian orang. Selain itu, merokok banyak ditemukan tanpa memandang usia, jenis kelamin, dan pekerjaan. Salah satu akibat dari kebiasaan merokok yaitu terjadinya pembentukan stain pada gigi. Penelitian ini bertujuan untuk mengetahui pengaruh kebiasaan merokok terhadap pembentukan stain pada gigi. Jenis penelitian ialah suatu literature review menggunakan database Google Scholar, PubMed, dan Wiley dengan topik terkait. Terdapat tujuh literatur yang memenuhi kriteria inklusi dan eksklusi serta telah melewati tahap penilaian jurnal menggunakan instrumen critical appraisal. Hasil penelitian mendapatkan frekuensi merokok yang paling banyak ditemukan ialah perokok kategori ringan dengan jumlah rokok yang dihisap 1-4 batang per hari. Pembentukan stain gigi secara keseluruhan pada semua literatur menunjukkan bahwa lebih banyak terjadinya pembentukan stain dibandingkan dengan yang tidak terjadi pembentukan stain. Berdasarkan frekuensi merokok, pembentukan stain pada gigi paling banyak terjadi pada perokok dengan kategori ringan. Simpulan penelitian ini ialah kebiasaan merokok dapat berpengaruh terhadap pembentukan stain pada gigi. Berdasarkan frekuensi merokok pembentukan stain pada gigi paling banyak ditemukan pada perokok dengan kategori ringan.
\end{abstract}

Kata kunci: merokok; stain; pewarnaan gigi

\section{PENDAHULUAN}

Merokok merupakan salah satu kebiasaan yang sudah menjadi kebutuhan hidup oleh sebagian orang dan tidak bisa ditinggalkan dalam kehidupan sehari-hari. ${ }^{1}$ Merokok banyak ditemui di mana saja. Hampir setiap tempat ditemukan orang yang sedang merokok tanpa memandang usia, jenis kelamin, dan pekerjaan. ${ }^{2}$ Kebiasaan merokok adalah suatu aktivitas menggunakan rokok dengan cara mengisap dan menghirup asap rokok. ${ }^{3}$

Southeast Asia Tobacco Control Alliance (SEATCA) pada tahun 2016 melaporkan bahwa, negara dengan jumlah perokok terbanyak di ASEAN yaitu 
Indonesia dengan jumlah 65,19 juta orang atau setara dengan $34 \%$ dari total penduduk Indonesia. ${ }^{4}$ Menurut data Riset Kesehatan Dasar (RISKESDAS) tahun 2018, prevalensi merokok di Indonesia mencapai $28,8 \%$. Provinsi Sulawesi Utara menempati peringkat kesepuluh dengan angka 29\%.5

Rokok merupakan gabungan dari berbagai bahan kimia berbahaya bagi kesehatan karena dapat menganggu hampir semua organ tubuh manusia. Kandungan bahan kimia pada rokok dapat mengakibatkan timbulnya pembentukan stain gigi. ${ }^{6}$ Stain atau noda berwarna pada gigi dapat memengaruhi estetika yang memberikan dampak psikologi yang cukup besar, terutama apabila terjadi pada gigi anterior. ${ }^{7}$ Stain dapat disebabkan karena kebiasaan merokok, karena asap rokok yang mengandung berbagai zat tersebut dapat menempel pada permukaan gigi yang lama kelamaan akan membuat permukaan gigi terasa kasar.

Tingginya prevalensi merokok dan terjadinya perubahan warna pada gigi karena kebiasaan merokok membuat penulis tertarik untuk melakukan suatu literature review terkait dengan pengaruh kebiasaan merokok terhadap pembentukan stain pada gigi.

\section{METODE PENELITIAN}

Penelitian ini dilaksanakan pada bulan Mei-Juli 2021. Jenis penelitian ini ialah suatu literature review. Pencarian data dengan cara mengakses jurnal dan artikel yang diperoleh dari database Google Scholar, Pubmed, dan Wiley. Tahap seleksi data dilakukan sesuai dengan kriteria inklusi dan eksklusi serta analisis data melalui The Joanna Briggs
Institute (JBI) critical appraisal.

\section{HASIL PENELITIAN}

Pada penelitian ini, literatur yang telah memenuhi kriteria inklusi dan eksklusi serta kelayakan telah teruji berjumlah tujuh artikel, terdiri dari tiga cross-sectional study dan empat studi deskriptif.

Tabel 1 memperlihatkan hasil pencarian literatur yang berjumlah tujuh literatur yang terdiri dari tiga cross-sectional study dan empat studi deskriptif.

Tabel 2 memperlihatkan bahwa keseluruhan literatur yang digunakan berasal dari Indonesia. Total subjek penelitian dalam tujuh literatur terdiri dari puluhan hingga ratusan dengan usia mulai dari 15 tahun hingga 57 tahun. Berdasarkan jenis kelamin, sebagian besar penelitian memiliki subjek berjenis kelamin laki-laki. Literatur dengan subjek paling banyak berjumlah 66 subjek.

Tabel 3 memperlihatkan bahwa kategori perokok yang paling banyak ditemukan pada semua literatur yaitu perokok ringan dengan jumlah rokok yang dihisap 1-4 batang per hari.

Tabel 4 memperlihatkan bahwa pembentukan stain pada gigi perokok lebih banyak terjadi. Empat dari tujuh literatur yang digunakan melaporkan pembentukan stain gigi pada semua subjek penelitian.

Tabel 5 memperlihatkan bahwa berdasarkan frekuensi merokok, pada perokok kategori ringan (mengonsumsi 1-4 batang per hari) paling banyak terjadi pembentukan stain gigi. Tiga literatur tidak mencantumkan stain pada gigi berdasarkan kategori perokok.

Tabel 1. Hasil pencarian literatur yang digunakan dalam penelitian

\begin{tabular}{|c|c|c|c|}
\hline $\begin{array}{l}\text { Peneliti dan } \\
\text { Tahun }\end{array}$ & Judul & $\begin{array}{c}\text { Desain studi, Sampel, Variabel, } \\
\text { Instrumen, Analisis }\end{array}$ & Rangkuman Hasil \\
\hline Khalisa, $2016^{8}$ & $\begin{array}{l}\text { Hubungan kebiasaan } \\
\text { merokok dengan } \\
\text { pembentukan stain (noda } \\
\text { gigi) pada pasien di Poli } \\
\text { Gigi RSUD Ratu Zalecha } \\
\text { Martapura }\end{array}$ & $\begin{array}{l}\text { Desain: Analitik observasional } \\
\text { Cross-sectional study } \\
\text { Sampel: } 30 \text { subjek (laki-laki) } \\
\text { Variabel: Kebiasaan merokok dan } \\
\text { pembentukan stain (noda gigi) } \\
\text { Instrumen: Kuesioner } \\
\text { Analisis: Chi-square }\end{array}$ & $\begin{array}{l}\text { Tidak terdapat hubungan } \\
\text { antara jumlah rokok yang } \\
\text { dihisap per hari dengan } \\
\text { terjadinya pembentukan } \\
\text { stain. }\end{array}$ \\
\hline $\begin{array}{l}\text { Oktanauli dan } \\
\text { Heriaw, } 2018^{9}\end{array}$ & $\begin{array}{l}\text { Distribusi frekuensi } \\
\text { perubahan warna email } \\
\text { gigi pada perokok }\end{array}$ & $\begin{array}{l}\text { Desain studi: Deskriptif Cross- } \\
\text { sectional study } \\
\text { Sampel: } 30 \text { subjek (laki-laki dan }\end{array}$ & $\begin{array}{l}\text { Terdapat hubungan yang } \\
\text { signifikan antara merokok } \\
\text { dengan perubahan warna }\end{array}$ \\
\hline
\end{tabular}




$\begin{array}{ll}\text { Aurellia, } & \text { Gambaran terbentuknya } \\ 2019^{10} & \text { stain gigi pada } \\ & \text { masyarakat perokok RT. } \\ & \text { 43 Sukabangun 1 } \\ & \text { Palembang }\end{array}$

Sopianah dan Kristiani, $2015^{11}$

Kasihani et al, $2020^{7}$

Sunardi, $2018^{12}$

Aprilia, 2019 ${ }^{13}$ Gambaran pewarnaan ekstrinsik dan kebiasaan merokok pada office boy di Drivingrange Marinir Cilandak Jakarta Selatan Tahun 2019 perempuan)

Variabel: Frekuensi merokok dan perubahan warna email gigi Instrumen: Mengulaskan oco pada permukaan labial dan palatal gigi kemudian dilakukan observasi perubahan warna gigi

Analisis: Analisis univariat Desain studi: Deskriptif Sampel: 66 subjek Variabel: Terbentuknya stain gigi Instrumen: Daftar pertanyaan dan pemeriksaan intra oral Analisis: Analisis univariat

Desain studi: Deskriptif Crosssectional study

Sampel: 15 subjek

Variabel: Kebiasaan merokok dan pewarnaan ekstrinsik

Instrumen: Kuesioner dan pemeriksaan intra oral Analisis: Korelasi risk Spearman Desain studi: Deskriptif Sampel: 15 subjek Variabel: Aktivitas risiko dan status stain ekstrinsik gigi Instrumen: Wawancara dan pemeriksaan stain pada gigi Analisis: Deskriptif Desain studi: Deskriptif Sampel: 21 subjek (laki-laki) Variabel: Pewarnaan ekstrinsik dan jumlah rokok

Instrumen: Wawancara dan pemeriksaan intra oral Analisis: Statistik deskriptif Desain studi: Deskriptif Sampel: 50 subjek (laki-laki) Variabel: Pewarnaan ekstrinsik dan kebiasaan merokok Instrumen: Pemeriksaan gigi dan wawancara Analisis: Statistik deskriptif email gigi

Banyaknya jumlah rokok yang dihisap perharinya tidak begitu memengaruhi terbentuknya stain (noda) gigi kecuali didukung dengan konsumsi rokok yang telah lama Tidak ada hubungan kebiasaan merokok dengan pewarnaan ekstrinsik

Sampel dengan kebiaasan merokok sebagian besar frekuensi ringan dan semua sampel mengalami stain ekstrinsik dengan kategori sedang.

Semakin banyak rokok yang dihisap per hari semakin memengaruhi terbentuknya pewarnaan ektrinsik

Semakin banyak jumlah rokok yang dihisap dalam satu hari berpengaruh terhadap terbentuknya pewarnaan ekstrinsik pada gigi.

Tabel 2. Distribusi jumlah subjek penelitian berdasarkan jenis kelamin dan usia

\begin{tabular}{|c|c|c|c|c|c|}
\hline \multirow[t]{3}{*}{ Peneliti } & \multirow{3}{*}{$\begin{array}{c}\text { Lokasi } \\
\text { Penelitian }\end{array}$} & \multicolumn{3}{|c|}{ Jumlah Subjek } & \multirow{3}{*}{ Umur (tahun) } \\
\hline & & \multirow[b]{2}{*}{ Total } & \multicolumn{2}{|c|}{ Jenis kelamin } & \\
\hline & & & Laki-laki & Perempuan & \\
\hline Khalisa $^{8}$ & Banjarmasin & 30 & 30 & 0 & $>18$ \\
\hline Oktanauli dan Heriaw ${ }^{9}$ & Jakarta & 30 & 26 & 4 & Tidak disebutkan \\
\hline Aurellia $^{10}$ & Palembang & 66 & \multicolumn{2}{|c|}{ Tidak disebutkan } & $15-50$ \\
\hline Sopianah dan Kristiani ${ }^{11}$ & Tasikmalaya & 15 & \multicolumn{2}{|c|}{ Tidak disebutkan } & $27-57$ \\
\hline Kasihani et $\mathrm{al}^{7}$ & Jakarta & 15 & \multicolumn{2}{|c|}{ Tidak disebutkan } & $>26$ \\
\hline Sunardi $^{12}$ & Jakarta & 21 & 21 & 0 & $20-40$ \\
\hline Aprilia $^{13}$ & Jakarta & 50 & 50 & 0 & Tidak disebutkan \\
\hline
\end{tabular}


Tabel 3. Distribusi jumlah subjek penelitian berdasarkan frekuensi merokok

\begin{tabular}{|c|c|c|c|c|c|c|}
\hline \multirow{3}{*}{ Peneliti } & \multicolumn{6}{|c|}{ Frekuensi merokok (jumlah rokok yang dihisap per hari) } \\
\hline & \multicolumn{2}{|c|}{$\begin{array}{c}\text { Perokok ringan } \\
\text { (1-4 batang) }\end{array}$} & \multicolumn{2}{|c|}{$\begin{array}{l}\text { Perokok sedang } \\
\text { (5-14 batang) }\end{array}$} & \multicolumn{2}{|c|}{$\begin{array}{c}\text { Perokok berat } \\
\text { (>15 batang) }\end{array}$} \\
\hline & $\mathrm{n}$ & $\%$ & $\mathrm{n}$ & $\%$ & $\mathrm{n}$ & $\%$ \\
\hline Khalisa $^{8}$ & 10 & 33,3 & 15 & 50 & 5 & 16,7 \\
\hline Oktanauli dan Heriaw ${ }^{9}$ & 13 & 43,3 & 14 & 46,7 & 3 & 10 \\
\hline Aurellia $^{10}$ & 37 & 56 & 19 & 28,8 & 10 & 15,2 \\
\hline Sopianah dan Kristiani ${ }^{11}$ & 6 & 40 & 6 & 40 & 3 & 20 \\
\hline Kasihani et al ${ }^{7}$ & 8 & 53 & 5 & 33 & 2 & 14 \\
\hline Sunardi $^{12}$ & 11 & 52 & 8 & 38 & 2 & 10 \\
\hline Aprilia $^{13}$ & 26 & 52 & 16 & 32 & 8 & 16 \\
\hline
\end{tabular}

Tabel 4. Distribusi jumlah subjek yang terjadi pembentukan stain pada gigi

\begin{tabular}{lcccccc}
\hline \multirow{2}{*}{ Peneliti } & \multicolumn{2}{c}{ Stain } & \multicolumn{2}{c}{ Tidak ada } & \multicolumn{2}{c}{ Total } \\
& $\mathrm{n}$ & $\%$ & $\mathrm{n}$ & $\%$ & $\mathrm{n}$ & $\%$ \\
\hline Khalisa $^{8}$ & 23 & 76,7 & 7 & 23,3 & 30 & 100 \\
Oktanauli dan Heriaw $^{9}$ & 30 & 100 & 0 & 0 & 30 & 100 \\
Aurellia $^{10}$ & 22 & 33,3 & 44 & 66,7 & 66 & 100 \\
Sopianah dan Kristiani $^{11}$ & 15 & 100 & 0 & 0 & 15 & 100 \\
Kasihani et al $^{7}$ & 15 & 100 & 0 & 0 & 15 & 100 \\
Sunardi $^{12}$ & 21 & 100 & 0 & 0 & 21 & 100 \\
Aprilia $^{13}$ & 44 & 88 & 6 & 12 & 50 & 100 \\
\hline
\end{tabular}

Tabel 5. Distribusi stain berdasarkan frekuensi merokok

\begin{tabular}{|c|c|c|c|c|c|c|}
\hline \multirow{4}{*}{ Peneliti } & \multicolumn{4}{|c|}{ Stain } & & \\
\hline & \multicolumn{2}{|c|}{ Perokok ringan } & \multicolumn{2}{|c|}{ Perokok sedang } & \multicolumn{2}{|c|}{ Perokok berat } \\
\hline & Ada & Tidak & Ada & Tidak & Ada & Tidak \\
\hline & \multicolumn{2}{|c|}{$\mathrm{n}$} & \multicolumn{2}{|c|}{$\mathrm{n}$} & \multicolumn{2}{|c|}{$\mathrm{n}$} \\
\hline Khalisa $^{8}$ & 9 & 1 & 9 & 6 & 5 & 0 \\
\hline Oktanauli dan Heriaw9 & \multicolumn{2}{|c|}{ Tidak disebutkan } & \multicolumn{2}{|c|}{ Tidak disebutkan } & \multicolumn{2}{|c|}{ Tidak disebutkan } \\
\hline Aurellia $^{10}$ & 7 & 30 & 7 & 12 & 8 & 2 \\
\hline Sopianah dan Kristiani ${ }^{11}$ & 6 & 0 & 6 & 0 & 3 & 0 \\
\hline Kasihani et al ${ }^{7}$ & \multicolumn{2}{|c|}{ Tidak disebutkan } & \multicolumn{2}{|c|}{ Tidak disebutkan } & \multicolumn{2}{|c|}{ Tidak disebutkan } \\
\hline Sunardi $^{12}$ & 11 & 0 & 8 & 0 & 2 & 0 \\
\hline Aprilia $^{13}$ & \multicolumn{2}{|c|}{ Tidak disebutkan } & \multicolumn{2}{|c|}{ Tidak disebutkan } & \multicolumn{2}{|c|}{ Tidak disebutkan } \\
\hline
\end{tabular}

\section{BAHASAN}

Kejadian merokok di Indonesia sampai saat ini masih sangat banyak dan prevalensinya terus meningkat. ${ }^{14}$ Hasil penelitian mengenai kebiasaaan merokok pada tujuh literatur berdasarkan frekuensi merokok menunjukkan bahwa total subjek penelitian yang merokok yaitu 227 subjek yang terbagi menjadi tiga kategori yaitu perokok ringan, perokok sedang, dan perokok berat.

Berdasarkan frekuensi merokok kategori perokok yang paling banyak ditemukan yaitu perokok ringan dengan jumlah rokok yang dikonsumsi 1-4 batang per hari. Data survei dari Global Youth Tobacco Survey (GYTS) tahun 2014 menyatakan bahwa 
sebagian besar masyarakat Indonesia mengonsumsi rokok sebanyak 1 batang per hari. ${ }^{15}$ Jumlah batang rokok yang di konsumsi masyarakat Indonesia terjadi peningkatan dari tahun 2011-2018. Menurut data terkini Kementerian Perindustrian tahun 2018, jumlah produksi rokok di Indonesia sebanyak 332,38 miliar. $^{16}$

Berbagai penelitian sebelumnya telah dilakukan sehubungan dengan frekuensi merokok, diantaranya penelitian Kasihani et $\mathrm{al}^{7}$ yang menyebutkan bahwa kategori perokok yang paling banyak ditemukan yaitu perokok ringan dengan jumlah rokok yang dihisap 1-4 batang per hari. Penelitian serupa juga dilakukan oleh Aprilia ${ }^{13}$ yang menyebutkan bahwa berdasarkan jumlah rokok paling banyak ditemukan yaitu perokok ringan (mengonsumsi rokok 1-4 batang per hari).

Salah satu akibat merokok ialah terbentuknya stain pada gigi. Hasil penelitian mengenai gambaran stain gigi pada semua literatur menunjukkan bahwa lebih banyak terjadi pembentukan stain pada gigi daripada yang tidak terjadi pembentukan stain pada gigi. Hal ini sejalan dengan penelitian Sodik $^{17}$ yang melaporkan bahwa bahaya rokok bagi rongga mulut dapat berpengaruh negatif secara langsung dan jangka panjang, di antaranya noda pada gigi (stain).

Terdapat tiga indikator kebiasaan merokok yang dapat memengaruhi pembentukan stain pada gigi salah satunya ialah frekuensi merokok. Semua literatur berdasarkan frekuensi merokok menunjukkan bahwa stain paling banyak ditemukan pada perokok kategori ringan dengan rokok yang dikonsumsi 1-4 batang per hari. Sunardi ${ }^{12}$ menyebutkan bahwa kategori perokok ringan (yang mengonsumsi 1-4 batang per hari) paling banyak ditemukan stain pada gigi. Hal ini disebabkan karena dalam sebatang rokok terdapat berbagai jenis bahan-bahan kimia berbahaya seperti tar yang dapat menyebabkan pembentukan stain pada gigi.

Penelitian oleh Aurellia ${ }^{10}$ menunjukkan hasil yang berbeda yaitu lebih banyak yang tidak terjadi pembentukan stain pada gigi dibandingkan terjadinya pembentukan stain pada gigi. Penelitian serupa juga dilakukan Khalisa $^{8}$ dan Aprilia $^{13}$ yang melaporkan bahwa terdapat subjek penelitian yang merokok tanpa terjadi pembentukan stain pada gigi. Hal ini disebabkan karena subjek penelitian sudah melakukan skeling sejak pertama kali merokok hingga dilakukan penelitian dan menyikat gigi sebanyak dua kali sehari. ${ }^{8}$ Adanya perbedaan hasil penelitian ini dengan beberapa penelitian sebelumnya sejalan dengan penelitian Bastian dan Reade yang menyatakan bahwa terjadinya pembentukan stain pada gigi lebih dipengaruhi oleh banyaknya bakteri plak gigi yang dapat menyerap dan melekatkan produk hasil pembakaran tembakau (tar) ke permukaan gigi. $^{8}$

Keterbatasan penelitian ini ialah data yang digunakan berupa data sekunder berasal dari literatur yang telah dipublikasikan dan tidak dapat diintervensi. Adanya perbedaan total subjek, lokasi penelitian yang beragam, serta pembatasan usia yang terlalu luas pada beberapa literatur dapat menyebabkan terjadinya bias.

\section{SIMPULAN}

Kebiasaan merokok dapat berpengaruh terhadap pembentukan stain pada gigi. Berdasarkan frekuensi merokok, pembentukan stain pada gigi paling banyak ditemukan pada perokok dengan kategori ringan.

\section{DAFTAR PUSTAKA}

1. Hajjah N. Perilaku sosial para perokok aktif dan respon terhadap poster peringatan bahaya merokok pada kemasan rokok (Studi deskriptif di Kota Bangkinang, Kabupaten Kampar). Jom FISIP. 2016; 3(1):1-15.

2. Kuntara W. Hubungan antara tingkat pengetahuan penyakit akibat merokok dengan perilaku merokok pada usia dewasa awal di Desa Kacangan Kecamatan Andong Kabupaten Boyolali [Naskah Publikasi]. Surakarta: Universitas Muhammadiyah Surakarta; 2012.

3. Rahmati W, Sodik MA. Perilaku merokok pada remaja. Institut Ilmu Kesehatan Strata Indonesia. 2021. [cited 2021 Apr 28]. Available from: https://osf.io/uefs5.

4. Lian TY, Dorotheo U. The Tobacco Control 
Atlas (4th ed). Ritthiphakdee B, Kolandai MA, Villarreiz D, Ratanachena S, Cho MM, Jirathanapiwat $\mathrm{W}$, et al., editors. Southeast Asia Tobacco Control Alliance (SEATCA): ASEAN region. Thailand: Publishing of Suetawan Co Ltd; 2018; p. 33-9.

5. Badan Penelitian dan Pengembangan Kesehatan. Hasil utama Riskesdas 2018. Jakarta: Kementerian Kesehatan Republik Indonesia, 2018; p. 52.

6. Ash.org. What's in a Cigarette? Action on smoking and health. 2018:1-4.

7. Kasihani NN, Budiarti R, Re PRR, Erwin, Mujahidah AF. Aktivitas risiko dan status stain ekstrinsik gigi pada masyarakat Rt $004 \mathrm{Rw} 001$ Kampung Bali Tanah Abang. J Dental Hygiene Therapy. 2020;1(47):16-20.

8. Khalisa E. Hubungan kebiasaan merokok dengan pembentukan stain (noda gigi) pada pasien di Poli Gigi RSUD Ratu Zalecha Martapura. Dentino. 2016;I(1): 27-31.

9. Oktanauli P, Heriaw NQ. Distribusi frekuensi perubahan warna email gigi pada perokok. Cakradonya Dental J. 2018; 9(2): 116-20.

10. Aurellia V. Gambaran terbentuknya stain (noda) gigi pada masyarakat perokok RT.43 Sukabangun 1 Palembang [Karya Tulis Ilmiah]. Palembang: Politeknik Kesehatan Palembang; 2019.

11. Sopianah Y, Kristiani A. Analisis hubungan kebiasaan merokok dengan pewarnaan ekstrinsik pada karyawan jurusan Keperawatan Gigi Politeknik Kesehatan Kemenkes Tasikmalaya. J Kesehatan Komunitas Indonesia. 2015;11(1).

12. Sunardi AO. Gambaran pewarnaan ekstrinsik dan jumlah rokok yang dihisap perhari pada anggota Karang Taruna Benda Barat RW 06 Depok [Karya Tulis Ilmiah]. Jakarta: Politeknik Kesehatan Kemenkes Jakarta 1; 2018.

13. Aprilia T. Gambaran pewarnaan ekstrinsik dan kebiasaan merokok pada office boy di Drivingrange Marinir Cilandak Jakarta Selatan Tahun 2019 [Karya Tulis Ilmiah]. Jakarta: Politeknik Kesehatan Kemenkes Jakarta 1; 2019.

14. Revien I, Supit ASR, Anindita PS. Kebiasaan merokok dan terjadinya smoker's melanosis. e-GIGI. 2020;8(2):44-53.

15. Kementerian Kesehatan RI. Perilaku merokok masyarakat Indonesia berdasarkan riskesdas 2007 dan 2013. Pusat Data dan Informasi Kementerian Kesehatan RI. 2015. h. 2-12.

16. IAKMI T. Atlas Tembakau Indonesia 2020. In: TCSC-IAKM, editor. Tobacco Control Support Center-Ikatan Ahli Kesehatan Masyarakat Indonesia (TCSC-IAKMI); 2020. p. 27-8.

17. Sodik MA. Merokok \& Bahayanya. Pekalongan: PT Nasya Expanding Manangement, 2018; p. 29. 